\title{
Analysis of the cornea donor data: an eye bank study
}

\section{Ayse Balikci Tufekci ${ }^{1}$, Sadik Gorkem Cevik${ }^{1}$, Neslihan Parmak ${ }^{1}$, Rahmi Duman ${ }^{2}$, Mediha Tok Cevik ${ }^{3}$, Burcu Kazanci ${ }^{4}$, Mehmet Emin Aslanci ${ }^{1}$, Ersin Yucel $^{1}$}

${ }^{1}$ Department of Ophthalmology, Bursa Yuksek Ihtisas Training and Research Hospital, Bursa, Turkey

${ }^{2}$ Department of Ophthalmology, Afyon Kocatepe University Medical School, Afyon, Turkey

${ }^{3}$ Department of Ophthalmology, Düzici State Hospital, Osmaniye, Turkey

${ }^{4}$ Department of Ophthalmology, Ankara Ulucanlar Training and Research Hospital, Ankara, Turkey

\begin{abstract}
Objectives. To analyse 1.5-year data of our newly established eye bank and to evaluate the factors affecting donor quality. Methods. Our bank's donor cornea data between July 2013 and November 2014 were retrospectively analysed. The effects of donor age, sex, and time from death to harvesting on the findings of specular microscopy were assessed. Results. A total of 139 corneas retrieved from 70 donors. The mean age of donors was $34.2 \pm 14.6$ (5-64) years. The mean time from death to harvesting was $6.7 \pm 2.9$ (1-13) hours; the mean time from collection to transplantation was $5.2 \pm 2.8$ (1-14) days. Age had a significant negative correlation with mean endothelial cell count (ECC), a significant positive correlation between mean cell area (MCA) and standard deviation (SD). Time from death to harvesting had a significant negative correlation with cell count and 6A; it had a significant positive correlation with SD, the coefficient of variation, and MCA. Conclusion. According to the results of the present study, ECC, MCA, and SD levels were greater in younger donors. Endothelial morphology was altered as the time from death to harvesting was prolonged; however, the alteration in cell morphology was not severe enough to alter transplantation success with the corneas being harvested within the first 13 hours.
\end{abstract}

Eur Res J 2016;2(1):30-35

Keywords: Eye Bank; cornea; specular microscopy; endothelial; donor

\section{Introduction}

Eye banks are special medical units responsible for harvesting donor corneal tissue required for the cornea transplantation from suitable donors, preserving harvested tissues under appropriate conditions, evaluating tissue quality for transplantation, transporting tissues to transplant centres under optimal conditions, registering patients who apply for keratoplasty procedure, as well as establishing and maintaining communication with the patients. Donor suitability, time from donor death to tissue harvesting, cornea storage conditions, and time of harvesting to transplantation are vital factors for graft survival during the time of harvesting to transplanting corneal tissue. Corneal storage duration is dependent on corneal preservation methods (tissue culture medium, organ culture, moist chamber); corneal tissue should be transplanted as soon as possible before irreversible degeneration occurs after 
donor death and during storage [1].

As a result of continuously increasing the number of patients entering keratoplasty waiting lists and prolonged waiting durations, Turkish Ministry of Health has recently funded the establishment of new eye banks in various cities. As of the time of the writing this paper, there are 28 functioning eye banks in Turkey. Our eye bank was established in July 2013 by ministerial approval of Turkish Ministry of Health and supplied 139 donor corneal tissues between July 2013 and November 2014. In the following we want to assess the first donor data of our newly established eye bank.

\section{Methods}

Data of donor corneas harvested at Bursa Yuksek Ihtisas Training and Research Hospital Eye Bank between July 2013 and November 2014 were retrospectively reviewed. Data on donor age, sex, time of death to harvesting, time from collection to transplantation, serology results, specular microscopy (SM) results, and donor usage were recorded. In specular microscopy, the Centre Method was used to determine the corneal endothelial count and endothelial structure (polymegathism and pleomorphism) (Konan Eye Bank Kerato Analyzer, Konan Medical Inc., Japan). The effects of donor age, sex, and time from death to cornea harvesting on the findings of specular microscopy were analysed. The local ethics committee approved the study. After being harvested from the cadavers using the sclerocorneal button technique, donor corneas were preserved in the preservation solution (Eusol C, Alchimia, Italy) at $4^{\circ} \mathrm{C}$; and endothelial photographs were taken to be examined for four times from all corneas by the same person using specular microscopy. For each donor cornea, endothelial cell count (ECC), mean cellular area (MCA), standard deviation (SD), hexagonality ratio $(6 \mathrm{~A})$, and coefficient of variance $(\mathrm{CV})$ were recorded. The donors were categorized into four age groups. Donor gender distribution, corneal side distribution, endothelial count, $\mathrm{SD}, \mathrm{CV}, 6 \mathrm{~A}, \mathrm{MCC}$, time from death to harvesting and time from collection to transplantation were compared across the four age groups.

\section{Statistical analysis}

Descriptive statistics included mean, standard deviation, median, minimum, maximum, frequency, and percentage. The distribution of study data was tested with the Kolmogorov-Smirnov test. Quantitative data were analysed with ANOVA and Kruskal-Wallis (Mann-Whitney U) tests. Chi-Square test was used for the analysis of qualitative data. SPSS 22.0 software package was used for all statistical comparisons.

\section{Results}

Among 70 donors included in the study, 16 (23\%) were female, and 54 (77\%) were male. During our study period, 139 corneal tissues were retrieved from 70 donors. A pair of corneas was harvested from 69 donors and a single cornea from 1 donor. The mean age of the donors was $34.2 \pm 14.6$ (5-64) years. The mean time from death to harvesting was $6.7 \pm 2.9$ (113) hours; the mean time from collection to transplantation at different centres was $5.2 \pm 2.8$ (1-14) days. The mean age of the transplant recipients was $45.8 \pm 25(1-88)$ years at various centres. The obtained corneas were serologically tested using anti-HIV, HBsAg, anti-HCV and VDRL tests. Two corneas were HBsAg positive and were thus disposed of.

Another cornea was disposed of by a recipient centre due to suspected infection. The findings of specular microscopy, age and sex group distribution of corneal tissues were shown in Table 1.

There were no significant differences between the age groups on gender distribution and the distribution of corneal tissue side. The cell count was significantly greater in the first age group (5-19 years) compared with the second (20-34 years), third (35-49 years), and fourth $(50-65$ years $)$ age groups $(p<0.001)$. The cell count was significantly greater in the second age group compared to the $3^{\text {rd }}$ and $4^{\text {th }}$ age groups $(p<0.001)$ (Table 2). The SD level was significantly lower in the first age group compared to the second, third, and fourth age groups $(p<0.001)$. It was also significantly lower in the second age group compared to the fourth age group $(p<0.001)$ (Table 2$)$. There were no significant differences between the age groups on $\mathrm{CV}$, $6 \mathrm{~A}$, time from death to harvesting, and time from collection to transplantation (Table 2). The first age group had a significantly lower MCA compared to the second, third, and fourth age groups $(p<0.001)$ The MCA level was significantly lower in the second age group compared to the $3^{\text {rd }}$ and $4^{\text {th }}$ age groups $(p<0.001)$ 
Table 1. Specular microscopy, age and sex group distribution of corneal tissues

\begin{tabular}{lccc}
\hline & Min-Max & Median & Mean \pm SD \\
\hline Donor Age & $5-64$ & 34 & $34.2 \pm 14.6$ \\
& $5-19$ & & $34(24.5 \%)$ \\
Age Groups & $20-34$ & & $37(26.6 \%)$ \\
& $35-49$ & & $43(30.9 \%)$ \\
Cell Count & $50-65$ & 2857 & $25(18.0 \%)$ \\
SD & $2008-3968$ & 106.0 & $2884.0 \pm 457.3$ \\
CV & $53.0-257.0$ & 30.0 & $112.7 \pm 36.2$ \\
6A & $19.0-60.0$ & 61.0 & $31.4 \pm 6.7$ \\
MCA & $39.0-81.0$ & 347.0 & $61.1 \pm 8.6$ \\
\hline
\end{tabular}

$\mathrm{SD}=$ Standart deviation, $\mathrm{CV}=$ coefficient of variance, $6 \mathrm{~A}=$ hexagonality ratio, $\mathrm{MCA}=$ mean cellular area

( Table 2).

Cell count, SD, CV, 6A, and MCA levels were not significantly different between both genders (Table1). Time from death to harvesting had a significant negative correlation between cell count and $6 \mathrm{~A}$ $(p=0.005)$. It had a significant positive correlation with $\mathrm{SD}, \mathrm{CV}(p<0.001$ for both), and MCA $(p=0.011)$ (Table 3$)$. Twenty-nine $(21 \%)$ of the harvested corneas were used at our hospital while the remaining 108 $(79 \%)$ corneas were sent to other requesting institutions. Two corneas had HBsAg positivity and were thus disposed of.

\section{Discussion}

Today, there is an estimated 4.9 million patients with bilateral corneal blindness worldwide, especially in the developing countries, who may potentially regain their visual ability with corneal transplantation. According to the World Health Organisation data, 120.000 keratoplasties (KP) operations were performed in 2000 worldwide [2, 3]. According to the data of the Turkish Ministry of Health, the numbers of keratoplasty operations were 1784 and 1921 in 2012 and 2013, respectively. The official number of patients who are in the cornea waiting lists is 4822 , although unofficial estimates put the number at $10.000[5,6]$.

Evaluation of donor candidacy according to certain standards is vital to operational success and preventing complications. For this purpose, the European Eye Bank Association (EEBA) and the Eye Bank Association of America (EBAA) have set up the minimum medical standards for donor candidacy [7, 8]. FDA undertakes supervision and certification of the eye banks in the United States. The available standards are reviewed twice a year, published by the American Academy of Ophthalmology, and

Table 2. Age groups with the distribution of specular microscopy findings.

\begin{tabular}{lccccc}
\hline Age groups & $\mathbf{5 - 1 9}$ Years & $\mathbf{2 0 - 3 4}$ Years & $\mathbf{3 5 - 4 9}$ Years & $\mathbf{5 0 - 6 5}$ Years & $\boldsymbol{p}$ \\
\hline Cell Count & $3319 \pm 361$ & $2947 \pm 358^{*}$ & $2685 \pm 366^{*} \#$ & $2518 \pm 326^{*} \#$ & $<0.001$ \\
SD & $95.2 \pm 42.6$ & $113.7 \pm 31.7^{*}$ & $114.9 \pm 26.9^{*}$ & $133.0 \pm 35.5^{*} \#$ & $<0.001$ \\
CV & $30.3 \pm 8.9$ & $32.7 \pm 6.4$ & $30.3 \pm 5.0$ & $32.6 \pm 5.8$ & 0.051 \\
6A & $63.9 \pm 10.0$ & $59.2 \pm 6.9$ & $59.9 \pm 8.2$ & $61.5 \pm 8.5$ & 0.111 \\
MCA & $304.8 \pm 38.5$ & $343.2 \pm 41.5^{*}$ & $377.7 \pm 52.9^{*} \#$ & $403.8 \pm 53.8^{*} \#$ & $<0.001$ \\
Harvesting time (h) & $6.1 \pm 2.7$ & $6.7 \pm 3.2$ & $6.7 \pm 2.8$ & $7.3+3.0$ & 0.504 \\
Transplantation time (h) & $4.7 \pm 3.1$ & $5.7 \pm 3.2$ & $4.8 \pm 2.5$ & $5.7 \pm 2.4$ & 0.212 \\
Recipient Age & $32.6 \pm 25.6$ & $42.6 \pm 23.9^{*}$ & $55.4 \pm 21.1^{* \#}$ & $52.1 \pm 20.7^{*}$ & 0.001 \\
\hline
\end{tabular}

$\mathrm{SD}=$ Standart deviation, $\mathrm{CV}=$ coefficient of variance, $6 \mathrm{~A}=$ hexagonality ratio, $\mathrm{MCA}=$ mean cellular area,

Kruskal-Wallis / ANOVA, ${ }^{*} p<0.05$ vs. $5-19$ years age group / $\# p<0.05$ vs. 20-34 years age group 
Table 3. Time from death to harvesting (Spearman Correlation)

\begin{tabular}{lcccccc}
\hline & & Cell Count & SD & CV & 6A & MCA \\
\hline Time from death to & $\mathrm{r}$ & -0.240 & 0.349 & 0.394 & -0.191 & 0.224 \\
harvesting (Hour) & $\mathrm{p}$ & 0.005 & 0.000 & 0.000 & 0.031 & 0.011 \\
\hline
\end{tabular}

$\mathrm{SD}=$ Standart deviation, $\mathrm{CV}=$ coefficient of variance, $6 \mathrm{~A}=$ hexagonality ratio, $\mathrm{MCA}=$ mean cellular area,

distributed to eye banks that are members of EBAA [9].

A donor cornea having appropriate criteria for transplantation is one of the most important factors determining the keratoplasty success. Therefore, a harvested cornea should undergo a specular microscopic and serological evaluation before keratoplasty. Some studies using specular microscopy have shown that race, sex, and age of a person may alter morphological properties of the endothelium [10, 11]. It has also been reported that certain factors such as time of donor death to cornea harvesting and cause of donor death may also influence endothelial morphology $[12,13]$.

Some studies have reported that endothelial count is the most important factor for donor quality. Endothelial cell density is markedly reduced until early puberty, especially in the first couple of years after birth. Former studies have shown that the mean endothelial cell count is reduced, and pleomorphism is markedly increased after the age of $50[14,15]$. Mean endothelial cell count is reportedly decreased by $0.3 \%$ to $0.6 \%$ each year while polymegathism and polymorphism simultaneously increase [16, 17]. Endothelial cell density is reduced between the second and eighth decades, dropping from 3000 to 4000 cell $/ \mathrm{mm} 2$ on average to as low as $2600 \mathrm{cell} / \mathrm{mm} 2$ on average. The hexagonal cell percentage also drops from $75 \%$ to $60 \%$ [18], reducing the rate of usage of corneas obtained from elderly donors for transplantation. However, many studies have reported that corneas from advanced-age donors can also be sometimes used for transplantation, and thus donor age does not affect donor survival. Linke et al. [17] showed that $32.1 \%$ of corneas from donors aged over 80 years met the appropriate criteria for transplantation. Patel et al. [19] similarly demonstrated that $80 \%$ of corneas from advanced age donors had suitable standards for transplantation. According to EBAA criteria reported in 2006, donors should be between 10 and 75 years of age [20]. Besides, the minimum medical standards set by EEBA in 2013, as well as those set by EBAA in 2012, do not specify an age limit for donor eligibility [7,8]. Kartal et al. [21] reported that ECC showed a significant negative correlation with age, being significantly greater in the first two decades of life. Likewise, our study revealed a negative correlation between ECC and age. Cell count was significantly higher in the first age group (5-19 years) compared with the second (2034 years), third (35-49 years), and fourth (50-65 years) age groups. Cell count was significantly greater in the second age group compared to the third and fourth age groups (Table 3). Our study also demonstrated a positive correlation between age and MCA, SD values. SD and MCA levels were significantly lower in the first age group compared to the second, third, and fourth age groups. MCA was significantly lower in the second age group compared to the 3rd and 4th age groups, while SD was significantly lower in the second age group than the fourth age group. CV and hexagonality did not show any age-based differences. Some studies in the literature failed to show any ageassociated differences in CV, MCA, and hexagonality, although some others have reported age-related differences in MCA [22, 23]. Kartal et al. [21] showed that $\mathrm{CV}$ and MCA were significantly lower in Group 1 and 2 ( $0-40$ years of age). In our study, mean endothelial count was $2884.0 \pm 457.3$, mean SD was $112.7 \pm 36.2$, mean $C V$ was $31.4 \pm 6.7$, mean MCA was $354.3 \pm 58.4$ and mean hexagonality was $61.1 \pm 8.6$. Since our mean donor age was lower than those reported in the literature, specular microscopy findings were ideal for transplantation in all of our donors. Some studies investigated gender-based differences in endothelial cell morphology, some of them reporting ECC differences between both genders, but some others not [24, 25]. Kartal et al. [21] reported that female donors had a greater MCA, while a study from India, reported higher CV in female donors [26]. Our results did not reveal any significant difference between both sexes. Previous studies have shown a significant impact of time from donor death to cornea harvesting on endothelial count $[17,27]$. EBAA recommends cornea harvesting within 20 hours in those aged less than 50 years, and within 18 hours in 
those aged equal to or greater than 50 years of age [20]. As a general rule, it is recommended that corneal harvesting should be completed within 12 hours [28], although there is still no consensus regarding the upper limit of this time, and it may well be prolonged in some cases [29]. Kartal et al. [21] showed that ECC was greatest in the $\leq 3$ hours group, although the difference was statistically non-significant. Our study showed a significant negative correlation between time from death to cornea harvesting and cell count, 6A. There was, however, a significant positive correlation between time from death to cornea harvesting and $\mathrm{SD}, \mathrm{CV}$, and MCA.

These results suggest that donor cornea quality is reduced as the time to the collection is increased. However, corneal endothelial structures did not undergo a degenerative process to preclude transplantation since corneas were harvested within maximum 13 hours. The harvested corneas should be serologically tested with anti-HIV, HBsAg, anti-HCV, and VDRL tests. Some domestic prevalence studies at different times have found a mean HBsAg positivity rate of $5 \%$ and a mean $\mathrm{HCV}$ positivity rate over $0.5 \%$ [30].

Kocazeybek et al. [31] reported corresponding figures of $6.6 \%$ and $0.9 \%$. Our study revealed HBsAg positivity in two corneas, which were disposed of. One other cornea was disposed of by another centre due to suspected infection.

Of the donor corneas collected by our bank over a period of 1.5 years, $21 \%$ were used for transplantation by our hospital and $79 \%$ by other institutions. Various studies have reported that about $30 \%$ of donor corneas cannot be used owing to either serological results or an inappropriate endothelial morphology on specular microscopy examination [8]. We suggest that, we had a higher rate of cornea usage and we generally used high-quality corneas, because our eye bank preferred relatively younger donors, it rejected corneas with suspected infection due to prolonged stay at intensive care unit or the corneas which would be inappropriate for transplantation due their general appearance, and it harvested corneas at $6.7 \pm 2.9$ hours on average after donor death.

The harvested corneas were sent by our eye bank to other clinics as soon as possible when they were not to be used at our hospital. Time from harvesting to transplantation was $5.2 \pm 2.8$ (1-14) days on average at other clinics.

In conclusion, we revealed that ECC, MCA, and $\mathrm{SD}$ values were greater in younger donors; endothelial morphology was altered as the time from death to harvesting was prolonged; however, the alteration in cell morphology was not too severe to alter transplant success with the corneas being harvested within first 13 hours. Eye banks should meticulously work in every step from donor harvesting to cornea transplantation. High-risk donor corneas should not be harvested. Harvested corneas should be examined serologically, as well as under specular microscopy, and they should be sent to centres of transplantation as soon as possible.

\section{Conflict of interest}

The authors disclosed no conflict of interest during the preparation or publication of this manuscript.

\section{Financing}

The authors disclosed that they did not receive any grant during conduction or writing of this study.

\section{References}

[1] Thuret G, Chiquet C, Bernal F, Acquart S, Romanet JP, Mouillon M, et al. Prospective, randomized clinical and endothelial evaluation of 2 storage times for corneal donor tissue in organ culture at 31 degrees $C$. Arch Ophthalmol. 2003 Apr;121(4):442-50.

[2] Human organ and tissue transplantation. Report by the Secretariat. Executive Board, EB112/5; 112th Session, May 2003

http://apps.who.int/gb/archive/pdf_files/EB112/eeb1125.pdf. Access date; 2013 Sep 09.

[3] Oliva MS, Schottman T, Gulati M. Turning the tide of corneal blindness. Indian J Ophthalmol. 2012 Sep-Oct;60(5):423-7.

[4] Turkiye Cumhuriyeti Saglik Bakanligi. Ankara: c201 2013Y11 Guncel Bekleme Listesi Hasta Istatistikleri.

https://organ.saglik.gov.tr/web/Content.aspx?menu=\%283\%29guncel_ bekleme_listesi. Access date: 2013 Sep 22.

[5] Turkiye Cumhuriyeti Saglik Bakanligi. Ankara: c2013 Organ ve Doku Dagitimi Istatistikleri.

https://organ.saglik.gov.tr/web/Content.aspx?menu=\%283\%29organ_v e_doku_dagitimi_istatistikleri. Access date: 2013 Sep 09.

[6] Demirsoy N, Yilmaz A. Kornea transplantasyonunun tip, etik ve hukuk acisindan onemi. Turkiye Klinikleri J Ophthalmology. 2012;21:171-83.

[7] European Eye Bank Association Directory. Minimum Medical Standards. Revision 1, 2013.

http://www.europeaneyebanks.org/downloads/EEBA\%20Minimum\%2 0Medical\%20Standards\%20Rev\%201\%20-\%202013Agreed.pdf.

Access date: 2015 Dec 18.

[8] Eye Bank Association of America. Medical Standards. Washington, DC: EBAA; 2012.

[9] Eye Bank Association of America Medical Advisory Board. Medical standards. Washington, DC: Eye Bank Association of America; November 2008.

[10] Rao SK, Ranjan Sen P, Fogla R, Gangadharan S, Padmanabhan P, Badrinath SS. Corneal endothelial cell density and morphology in normal Indianeyes. Cornea. 2000 Nov;19(6):820-3.

[11] Abib FC, Barreto J. Behavior of corneal endothelial densityover a lifetime. J Cataract Refract Surg. 2001 Oct;27(10):1574-8.

[12] Reinhart WJ. Eye banking methods and standards. In Krachmer JH, 
Mannis MJ, Holland EJ. Cornea. Fundamentals of cornea and external diseases. St. Louis: Mosby; 1997. P. 485-491.

[13] Grabska-Liberek I, Szaflik J, Brix-Warzecha M. The importance of various factors relating to the morphological quality of corneas used for PKP by the Warsaw Eye Bank from 1996 to 2002. Ann Transplant. 2003;8(2):26-31.

[14] Wilson RF, Roper-Hall MJ: Effect of age on the endothelial cell count in the normal eye. Br J Ophthalmol. 1982 Aug;66(8):513-5.

[15] Kozer L, Manav G, Sezen F, Akova Y. Yasa bagli kornea endotel degisimleri. T Oft Gaz. 1987;17:213-16.

[16] Yunliang S, Yuqiang H, Ying-Peng L, Ming-Zhi Z, Lam DS, Rao SK. Corneal endothelial cell density and morphology in healthy Chinese eyes. Cornea. 2007 Feb;26(2):130-2.

[17] Linke SJ, Eddy M, Bednarz J, Fricke O, Wulff B, Schroder A, et al. Thirty years of cornea cultivation: long term experience in a single eye bank. Acta Ophthalmol. 2013 Sep;91(6):571-8.

[18] McDermott ML, Atluri HKS: Kornea Endoteli. Yanoff M, Duker JS (Eds.). BavdekT (Çeviri editörü). Oftalmoloji. İkinci baskı. İstanbul Hayat Yayınc1lık 2007; 422-30.

[19] Patel HY, Brookes NH, Moffatt L, SherwinT, Ormonde S, Clover GM et al. The New Zealand National Eye Bank study 1991-2003: a review of the source and management of corneal tissue. Cornea. 2005 Jul;24(5):576-82.

[20] Eye Bank Association of America. MedicalStandards. Washington, DC: EBAA; 2006.

[21] Kartal B, Kandemir B, Akmaz B, Kugu S, Ozertuurk Y, Set T, et al. Kartal Egitim ve Arastirma Hastanesi kornea bankasi donorlerine ait spekuler mikroskopi verileri. Turk J Ophthalmol. 2014;44:190-5.

[22] Matsuda M, Yee RW, Glasser DB, Geroski DH, Edelhauser HF. Specular microscopic evaluation of donor corneal endothelium. Arch
Ophthalmol. 1986 Feb;104(2):259-62.

[23] Mohammad-Salih PA. Corneal endothelial cell density and morphology in normal Malay eyes. Med J Malaysia. 2011 Oct;66(4):300-3.

[24] Padilla MD, Sibayan SA, Gonzales CS. Corneal endothelial cell density and morphology in normal Filipino eyes. Cornea. 2004 Mar;23(2):129-35.

[25] Hashemian MN, Moghimi S, Fard MA, Fallah MR, Mansouri MR. Corneal endothelial cell density and morphology in normal Iranian eyes. BMC Ophthalmol. 2006 Mar 6;6:9.

[26] Sopapornamorn N, Lekskul M, Panichkul S. Corneal endothelial cell density and morphology in Phramongkutklao Hospital. Clin Ophthalmol. 2008 Mar;2(1):147-51.

[27] Anderson J, Ehlers N. The influence of donor age and postmortem time on corneal graft survival and thickness when employing banked donor materil. Acta Ophthalmol (Copenh). 1988 Jun;66(3):313-7.

[28] Pels E, Beele H, Claerhout I. Eye bank issues: II.Preservation techniques: warm versus cold storage. Int Ophthalmol. 2008 Jun;28(3):155-63.

[29] Kryczka T, Szaflik J, Midelfart A. Influence of donorage, postmortem time and cold storage on metabolic profile of human cornea. Acta Ophthalmol. 2013 Feb;91(1):83-7.

[30] Resit M, Balık U. Turkiye'de viral hepatitlerin epidemiyolojisi.(Bir meta analiz). In: Kilicturgay K, ed. Viral Hepatit'98. Ankara: Viral Hepatitle Savasim Dernegi, 1998:10-39.

[31] Kocazeybek B, Cakan H, Sansoy N, Kucukates E, Ozdemir F. Kornea transplantasyonunda donor serolojisinin degerlendirilmesi. Klimik Derg. 2000;13(3):101-3. 